\title{
Implementation Of Effective Capstone Projects In Undergraduate Manufacturing Design Engineering Program
}

\author{
Shekar Viswanathan, National University, USA
}

\begin{abstract}
Final program projects (capstone course) in manufacturing design engineering technology at National University are intensive experiences in critical thinking and analysis, designed to broaden students' perspectives and provide an opportunity for integration of coursework in the area of manufacturing design engineering. This paper focuses on three specific capstone projects that were worked on in an undergraduate manufacturing design engineering program. The projects include an office chair design, development of an improved balloon marker placement system for catheter manufacturing, and a modular motorcycle helmet design. This paper summarizes the design methodologies and strategies that were adopted by the students and faculty. In addition, this paper draws on the experiences gained from working on these projects to describe how a capstone project in manufacturing design engineering should be designed for maximum effectiveness. In this context, this paper presents a useful do's and don'ts list.
\end{abstract}

Keywords: Capstone Project; Manufacturing Design Engineering; Critical Thinking and Analysis; Design Methodologies

\section{INTRODUCTION}

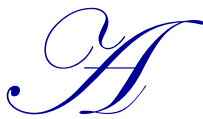

capstone course can provide an invigorating experience to students in their program of study since it integrates concepts and skills learned throughout the academic tenure. These projects allow students to gain valuable experiences in critical analysis, broaden their perspectives and give them an opportunity to understand how the materials learned in their coursework has relevance in their area of specialization ${ }^{1}$. This is because students pick on projects that require them to apply the knowledge gained from the program to solve multi-faceted problems similar to those they may encounter in their post-academic job environments. The students, under the guidance of a faculty advisor, select a problem to work on for their project, analyze the problem, and formulate a detailed plan to reach a solution, perform necessary evaluations and/or experimentations, identify and/or propose meaningful results and solutions, test the proposal to the extent possible, prepare a detailed report, and present their completed project. The 'front end' project plan and the 'back end' documentation and presentation are both important elements ${ }^{1}$. Faculty project advisors ensure that the problems they assign not only cater to the students' interests but also are helpful in reinforcing the concepts the students were taught as part of their course work. Projects are usually done in teams; occasionally, individuals who have personal constraints are allowed to work alone.

Typical learning outcomes for a project assigned at the culmination of a degree program include the ability to:

- Define a specific problem or study and evaluate critically a given project's feasibility.

- Present a comprehensive review of relevant literature.

- Identify sources of relevant data, generate and/or gather data as appropriate, and provide in-depth analyses.

- Identify, describe, and apply appropriate models for drawing conclusions.

- Create a comprehensive project report based on the findings that relate to all essential elements of the project.

- Defend the project's findings during oral presentation to faculty, class, and, if applicable, to external project sponsors/clients. 
National University's courses are offered in an intensive one-course-at-a-time, one course per month format. This includes 45 instructor-student contact hours per month; capstone projects require two courses done over a three-month period. Since these constraints require projects to be completed within a time intensive setting, preparation and execution have to be flawless to meet the learning outcomes previously established. There is little room for error or slack. This paper presents a process to select, and implement an undergraduate capstone project successfully. In addition, this paper presents the lessons learned in a 'Do's and Don'ts' list.

\section{LITERATURE REVIEW}

Engineering Criteria by the Accreditation Board for Engineering and Technology (ABET, 2016) mandate an outcome based assessment of graduating engineers' abilities to apply technical and other professional skills to solve real-world engineering problems. The capstone courses have been widely implemented so as to help build and enhance these recommended skill sets (Omar, 2014). In addition, the nation's current focus on preparing undergraduate students for engineering practice has also brought serious attention to the quality of the capstone projects as these are used to evaluate the effectiveness of an engineering program. The emphasis on quality capstone projects is part of an effort to not only ensure that graduates are fully prepared for engineering practice but also to increase and expand the professional competency of the engineering workforce. The Accreditation Board for Engineering and Technology (ABET, 2016) emphasizes that the engineering curricula include components that would equip students with the tools needed to identify, formulate, and propose engineering solutions to solve industrial problems as well as contemporary social or global problems. In other words, ABET emphasizes the need for engineering courses that build teamwork, communication, and project based skills. The capstone courses are designed to help build and enhance these very skill sets (Franchetti, 2012). The engineering design process imparted to the students incorporate the development of analytical, critical thinking, synthesis, and communication skills - fundamental skills that will satisfy the needs of the industry.

Todd et al. (1995) who surveyed capstone engineering courses throughout North America found that many engineering programs were using senior design/capstone-type courses to help prepare students for engineering practice, and a significant number of institutions engaged industrial clients to sponsor capstone projects. They concluded that the intensive faculty investment was valuable in producing competent engineering graduates.

Capstone projects are included in engineering curricula to integrate multi-disciplinary subjects and teach professional skills that are difficult to impart in a traditional lectured course. Since these projects serve to transition students into professional engineers, they have a direct impact on a university's industry reputation and ranking (Ward, 2013). Capstone design projects may be completed individually or as part of a group depending on the course or the overall program design. Since teamwork is considered a critical skill to succeed in the professional world, most capstone design courses require students to accomplish a design project in a team setting (Zhou \& Pazos, 2014). Mosher (2015) recommended that in order to develop a high-quality capstone course for technology undergraduates, it is important to have appropriate scoping and planning of the project with the client ahead of time, ownership and buy-in from students through controlled project and team selection, high tolerance for ambiguity and uncertainty as students work through the details of the project, and balanced methods of individual and group accountability. It is clear from the literature that careful planning and implementation is required for a successful capstone project.

\section{MATERIALS AND METHODS}

Figure 1 presents a list of the activities associated with this design course. They could be divided into three major segments: problem definition, problem analysis and design process, and finally, prototyping and manufacturing strategy. Figure 1 also lists the skills required to complete the design. The materials taught and the skills developed in various courses are used to complete the design. 
Figure 1. A List of the Activities Associated With This Design Course

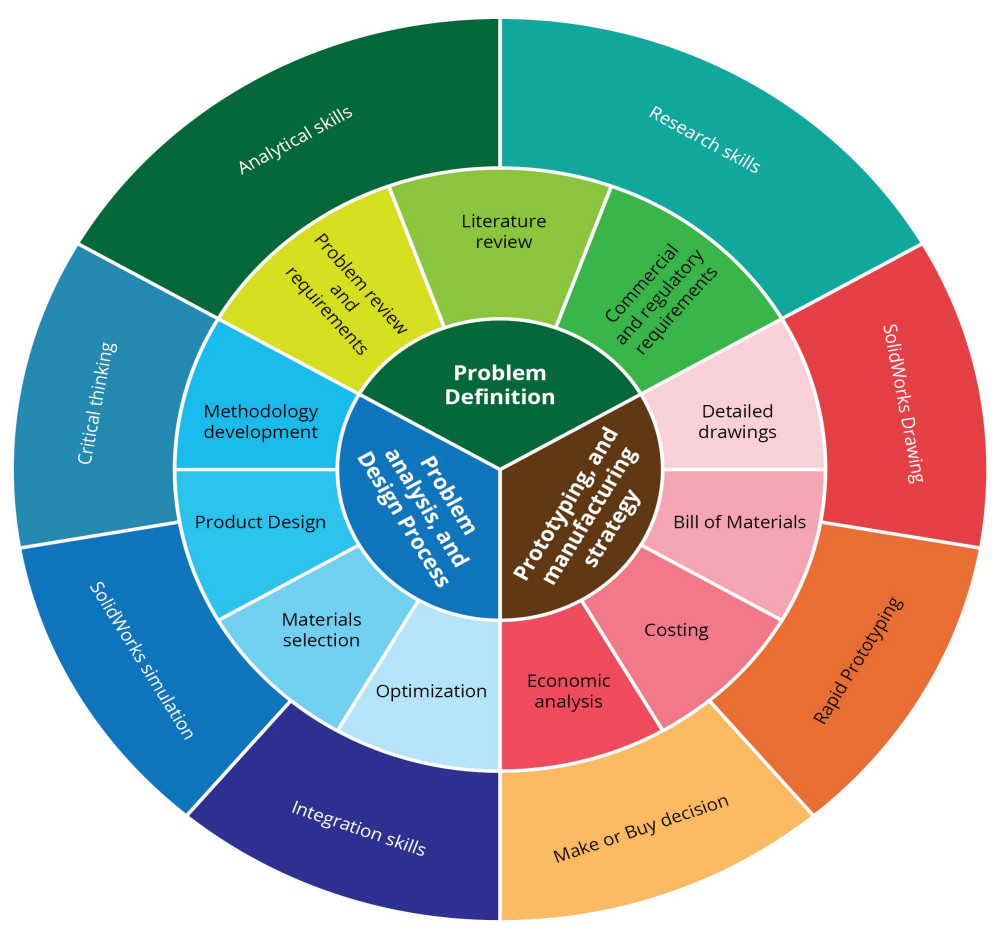

The Integrated Capstone Project Course in National University's curriculum is the last two classes taken by the students before graduation. The two classes run for three instructional months. Students are allowed to take only one course per month during which they are required to intensely focus on their chosen project. The first class $\left(1^{\text {st }}\right.$ month) focuses on establishing a project proposal with clearly defined needs whereas in the second course ( $2^{\text {nd }}$ and $3^{\text {rd }}$ month), students solve the problem and present the findings to a panel of faculty members. There are two different approaches adopted in selecting projects. In the first approach, instructors sponsor projects in consultation with employers. In the second approach, employers directly sponsor projects to their employees who are students at the university. The decision to employ these two different approaches was made to help evaluate the two and use the information to streamline the capstone process. No matter which approach is adopted, the capstone project requires that the students work on real problems of significant issue in any of the following fields: engineering, technology, science, or business. A team consisting of two to three students work on each project. Since the goal of the capstone project is to demonstrate students' mastery over all aspects of the area including problem identification, technology selection and integration, risk analysis, project management, and implementation, each student team is advised to pick students who can offer their expertise in these varied areas. These teams work with faculty members and representatives of the sponsors to develop detailed, specific, and implementable solutions. At the end of the course, students present their team's project to the faculty panel and members of sponsoring companies. In 2012-2016, eight sets of capstone project classes were completed. Three of the eight projects that were most successful are discussed in this paper.

\section{Employer Sponsored Project}

\section{Development of an Improved Balloon Marker Placement System for Catheter Manufacturing}

Abbott Vascular, Inc. manufactures cardiac catheters (Figure 2) for use by physicians to open blood vessels that are partially obstructed in coronary artery disease. A group of four students who worked in the manufacturing department at Abbott chose to use the Capstone project to address a newly identified issue impacting manufacturing efficiency. 


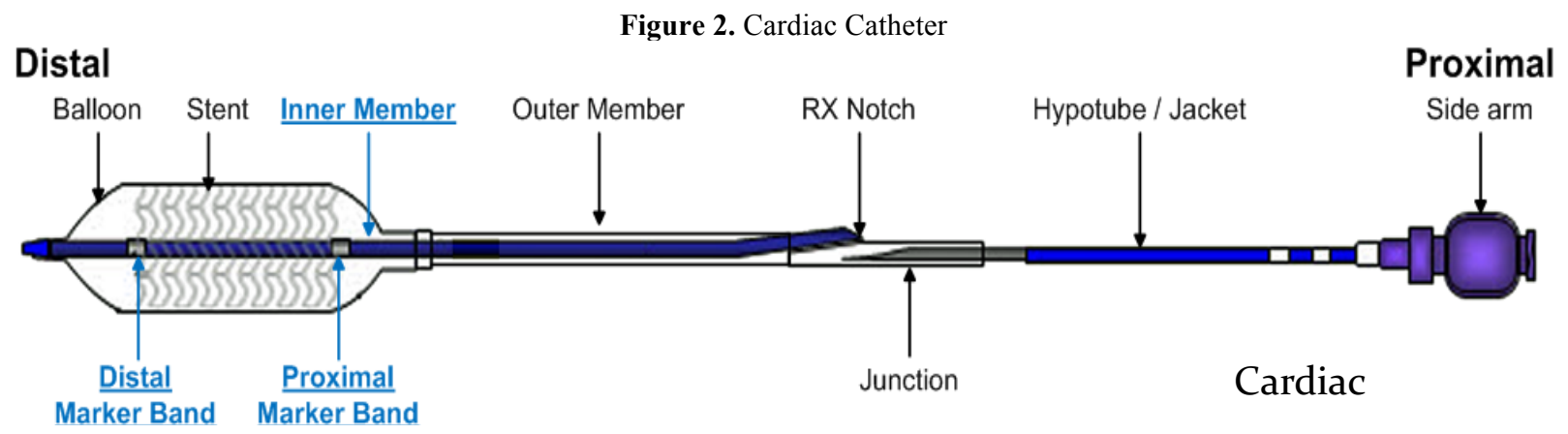

Analysis of manufacturing line yields and product scrap led to the identification of a specific defect being responsible for the majority of the scrap. The issue related to the consistent placement of 2 radio-opaque bands at either end of the balloon, which enable the physician to correctly position the balloon within a blood vessel under fluoroscopy. Manufacturing of catheters is surprisingly a hands-on process including the operator-mediated physical placement of the radio-opaque bands using visual guides. The entire process requires (1) manual setup of workspace and alignment tool for a specific catheter size, (2) physical placement of band within a $0.1 \mathrm{~mm}$ tolerance, (3) pre-crimping of band with tweezers, (4) insertion into swaging machine for final crimping, followed by (5) visual confirmation of band spacing against a laminated template. This process is performed $\sim 2,400$ times per work shift by a single operator. The process depends on the accurate visual alignment by the operator throughout the eight-hour work shift. The three critical steps are (1) positioning the marker bands, (2) pre-crimping the bands, and (3) verifying the band positions. The goal of the project undertaken by the students was to eliminate relatively subjective decisions on the part of the operators so that it would improve product yields as well as the ergonomics of the workstation.

\section{Instructor Sponsored Projects}

The first project dealt with the design an ergonomic office chair ready for manufacturing by IKEA, the largest furniture retailer in the world. The office chair is the most frequently used piece of office equipment. It is presently estimated that 45 million American workers spend a significant amount of time each day using a computer and keyboard. Approximately 30 million workers use the office chair, computer, keyboard, and pointing devices as their primary work equipment each day, all day, and up to 8 hours per day or more. Computer use has been linked to several types of injuries such as "Upper Extremity Repetitive Stress Injuries" and "Work Related Musculoskeletal Disorders" (WRMSDs). The upper extremities (UE) include arms, forearms, wrists, hands, fingers, neck, and back while the lower extremities (LE) include the legs. Most office chairs, today, offer few ergonomic features that are considered a must. To combat this issue, the students were asked to design for their capstone project a chair that would accommodate individuals who weighed $250 \mathrm{lbs}$, and were 6' 6" in height. The chair design should include ergonomic features that would offer comfortable seating during the eight hours or more they spend in their office environments. The students were asked to provide design details needed for readily manufacturing the chair. These included ergonomic and eco features, specification, state of the art cushions, material section, cost, manufacturing process, and the strategies used to evaluate and arrive at its ergonomic features. The students were asked to consider the following variables: tension adjustment, chair tilt lock, seat height, arm height, contoured seat cushions, width adjustable arms, synchro tilt movement, waterfall seat edge, and retractable settings.

The second project was to design a modular motor cycle helmet ready for manufacturing. The helmet designed should be one that could be used by individuals with a head circumference ranging between 20 and 25 inches. The helmet should be comfortable for the rider to wear it for a continuous stretch of three hours. In addition, the weight of the helmet should not exceed $2.2 \mathrm{lbs}$ and its cost should not exceed $\$ 190$ (based on 10,000 units per year). The helmet must provide a minimum peripheral side vision of 105 degrees on each side. The design must meet Federal Motor Vehicle Safety Standard No. 218 (49 CFR Sec. 571.218). The students were asked to provide design details necessary for the helmet to be readily manufactured such as its ergonomic and eco features. The students were also reminded that they had to keep in mind the following while designing their helmet: state of art comfort padding, good retention system, right choice of material, affordable price, feasible manufacturing process, and strategies they could use to determine 
if their helmet satisfied the given criteria. The manufactured helmet had to also to include full face to $3 / 4$ face option (swivel), zero loss of peripheral field of view, ambient noise threshold below 40dB, UV Day / Night lens, washable interior liner (preferably of dry-wick material), ventilation through entire helmet, support for integrated Bluetooth communications, and support for GoPro mounting (or fully integrated video/audio recording).

\section{Capstone Project Process}

Since the Capstone project duration is short, National University has a created a clear step-by-step process to help students complete their Capstone projects effectively and within the given time frame. Instructors and project advisors are also given similar guidelines so that they can provide their students with the instruction and guidance they need to successfully complete their project. The infrastructure and associated assistance are built for students and faculty members to get assistance as and when required. Instructors lead the project class and provide whatever advice the students seek with reference to their specific projects. They work with students throughout the capstone process and continually monitor their students' progress on their project. In some instances, the capstone instructors and project advisors could be one at the same. Corporate sponsors, when involved, would ensure that the sponsored projects are consistent with corporate needs. Below is the list of steps that have been developed for students, instructors, and project advisors to follow.

All students will:

1. Consult with faculty member(s) of their choice (project advisors / subject matter experts), regarding various aspects of the project

2. Develop a proposal that defines the scope and schedule of the project in consultation with the project advisor(s), sponsor, and instructor for the capstone class.

3. Develop the project collaboratively with other team members from the class.

4. Communicate clearly with the team members regarding their assigned work and seek help from team members if and when required.

5. Show project progress continuously throughout the life schedule of the project

6. Deliver a project report on or before the final presentation

The instructors will:

1. Ensure that the project selected is relevant to the student's area of specialization, has academic relevance, and will produce learning outcomes relevant to the program.

2. Review that the project selected is feasible within the timeframe allotted.

3. Help refine the project goals and outcomes as needed.

4. Identify and provide any help required to have a good start on the project.

5. Consult with the project sponsor with regard to all issues including project goals, access to data, confidentiality, and project details

6. Develop a clear assessment system with minimal ambiguity.

7. Monitor the students' progress on a weekly basis to ensure a successful capstone experience

The project advisors will:

1. Review that the project selected is feasible within the timeframe allotted.

2. Help refine the project goals and outcomes by working with students, project sponsors, and instructors.

3. Identify and provide any help required to have a good start on the project.

4. Monitor the students' progress on a weekly basis to ensure a successful Capstone experience.

5. Ensure that the project work submitted is the students' original work.

6. Ensure that the project outcome meets the requirements specified in the description and guidelines. 
The project sponsors will:

1. Develop a written list of available projects, organizational letter of support and expected outcomes

2. Meet face to face with the student team and discuss project details periodically.

3. Communicate periodically clearly regarding the goals of the project.

4. Provide data related to the project including access to project site if required.

5. Evaluate the feasibility of completing the project through discussions with the student team, and instructor.

\section{Course Logistics and Structure}

The capstone course spans over three months. At the outset, a course outline with instructional plan is provided to the students as well as to the project advisors and sponsors so as to familiarize all with the course. Each week, a set of assignments to be done/covered (or due) is defined (Table 1). During the course time, students meet with the course instructor twice a week during the first month and once a week during the second and third months. The students are asked to prepare a formal proposal that defines the scope of the project, lays out the requirements and expectations, identifies team members' roles and responsibilities, and lists the timeline of activities. Since the entire project has to be completed in three months, including all documentation, student teams are asked to schedule weekly status meetings with the instructor. These are formal meetings in which each team member is required to present a report on his/her particular activities and the status of his/her individual deliverables during the preceding week. Attendance at these meetings is mandatory. Failure to attend these meetings and/ or a show of chronic inactivity as determined from the weekly status report will significantly affect a team member's participation credit. Teams are also expected to meet twice a month with their project sponsor to ensure that their work remains aligned to their sponsor's vision and expectations. Sponsors are viewed first as a customer and only secondly as a resource. Hence it is both the team's and instructor's responsibility to make sure that the work proceeds as per the plan. To accomplish this, teams are required to present their project's progress to the instructor each month. In addition, a project post-mortem is held to ensure that the proposed results are indeed the best solutions to the problem worked on in the capstone project. A presentation is finally made to the review committee (faculty members, and Dean) and sponsors at the end of the project.

Table 1. Instructional Plan for the Course

\begin{tabular}{c|l|l|l}
\hline Week & \multicolumn{1}{|c|}{ Assigned Readings } & \multicolumn{1}{|c}{ Assignments } & \multicolumn{1}{|c}{ Due Dates and Times } \\
\hline 1 & $\begin{array}{l}\text { Course outline, Capstone } \\
\text { project requirements }\end{array}$ & $\begin{array}{l}\text { Form team, } \\
\text { Define a problem, } \\
\text { Select a sponsor-defined or instructor- } \\
\text { defined project }\end{array}$ & Week 1 Sunday, midnight (PST) \\
\hline 2 & $\begin{array}{l}\text { Hypothesis, Problem } \\
\text { definition, Needs analysis }\end{array}$ & $\begin{array}{c}\text { Complete Chapter 1 } \\
\text { Identify key relevant papers and internal } \\
\text { sponsor documents }\end{array}$ & Week 3 Sunday, midnight (PST) \\
\hline 3 & Library Search & $\begin{array}{l}\text { Complete Chapter 2 } \\
\text { Develop Methodology Complete Chapter } \\
3\end{array}$ & Week 5 Sunday, midnight (PST) \\
\hline 4 & Research Papers & $\begin{array}{l}\text { Collect data } \\
\text { Analyze data } \\
\text { Collect data } \\
\text { Analyze data. } \\
\text { Complete an in-depth analysis of all } \\
\text { applicable variables }\end{array}$ & Week 6 Sunday, midnight (PST) \\
\hline 5 & Research Papers & $\begin{array}{l}\text { Complete Chapter 4 } \\
\text { Week 7 Sunday, midnight (PST) }\end{array}$ \\
\hline 7 & Research Papers & Research Papers & Week 8 Sunday, midnight (PST) \\
\hline
\end{tabular}

(Table 1 continued on next page) 
(Table 1 continued)

\begin{tabular}{|c|c|c|c|}
\hline Week & Assigned Readings & Assignments & Due Dates and Times \\
\hline 9 & Research papers & $\begin{array}{l}\text { Complete Chapter 5, Abstract, } \\
\text { Table of Contents }\end{array}$ & Week 9 Sunday, midnight (PST) \\
\hline 10 & Steps for Thesis Guidelines & Complete the entire thesis & Week 10 Sunday, midnight (PST) \\
\hline 11 & $\begin{array}{l}\text { Visual Aids Preparation } \\
\text { Guidelines for Oral } \\
\text { Presentation }\end{array}$ & $\begin{array}{l}\text { Complete PPTs for Presentation and } \\
\text { Practice Presentation }\end{array}$ & Week 11 Sunday, midnight (PST) \\
\hline 12 & $\begin{array}{l}\text { Guidelines for Oral } \\
\text { Presentation }\end{array}$ & Final Presentation & Week 12 Saturday or thereabout \\
\hline
\end{tabular}

Chapter 1: Introduction - The statement of the problem, background of why this problem needs to be studied.

Chapter 2: Literature Review - This section should contain all work related to the proposed topic including chronological research progress made to date.

Chapter 3: Methodology - Answers the question "How do you plan to study this problem?"

Chapter 4: Findings - Answers the question "What were the actual results of the study?"

Chapter 5: Conclusions and Recommendations - Answers the question "So what?"

References: Published peer reviewed documents and internal reports.

A major goal of the Capstone project is to familiarize students with the corporate team approach where responsibility for getting things done belongs to the team and its members. A typical class has $12-15$ students, and these students are grouped into five project teams. This size provides students with opportunities to get personal attention from the faculty supervising their projects. Each class meeting consists of a lecture and personal interaction with capstone project team members. The goal of these lectures is to help reinforce students' knowledge of the program specialization and project management practices. The intent for the personal interactions is to give students and instructors an opportunity to discuss the project. By the third week of the capstone course, each team is asked to meet the instructor alone to review the progress made and get answers to relevant questions. This 30-45 minute status meeting each week gives students a chance to allow their instructor to gain some visibility into team performance, dynamics, and effort invested by individual team members. In addition, the status meetings ensure that each team makes steady, and consistent progress towards completing the project.

\section{RESULTS AND DISCUSSION}

\section{Employer Sponsored Project}

The team understood the problem relating to the catheter fairly well as they had worked on either the specific product line or similar manufacturing lines in varying capacities. The project involved the design, development, and testing of two tools that would eliminate operator-induced variability. The approach was to eliminate the visual component as much as possible and replace it with mechanical constraints for steps 1-3 (tool 1), and step 5 (tool 2). The project required students to participate in the following tasks: tool material selection, tool manufacturing process, process implementation, medical device regulatory approval, costs savings, and sorting manufacturing implementation issues, as well as satisfying training needs. Tool \#1 included the ability to remove operator dependency in the first three steps of the process (Fig. 3) and Tool \#2 simplified the verification step and was derived from the first tool (Fig. 4).

Since this project was of sufficient value to the corporation, the sponsor approved permission for half the team to spend up to three hours of their daily work shift at the company. Other team members contributed after their normal shift was complete. Additionally, the sponsor enabled pilot manufacturing tests of the developed tools, which allowed the team to provide actual manufacturing test data during the time frame of the project. Since it was a corporate project and it was related to a medical device, the team had to ensure that they followed all of Abbott product and process development guidelines for this project. Also, the entire team was made up of members who were employees of Abbott and as such were familiar with all of the corporate requirements.

The team followed a modified phase-gate process based on milestones including project proposal, requirements documentation, design review, prototyping, test plan development, and test plan results (Fig 3, tool \#1; Fig 4, tool \#2). 
Figure 3. Design Process - Hand Drawings to CAD to Prototype to Final Tool

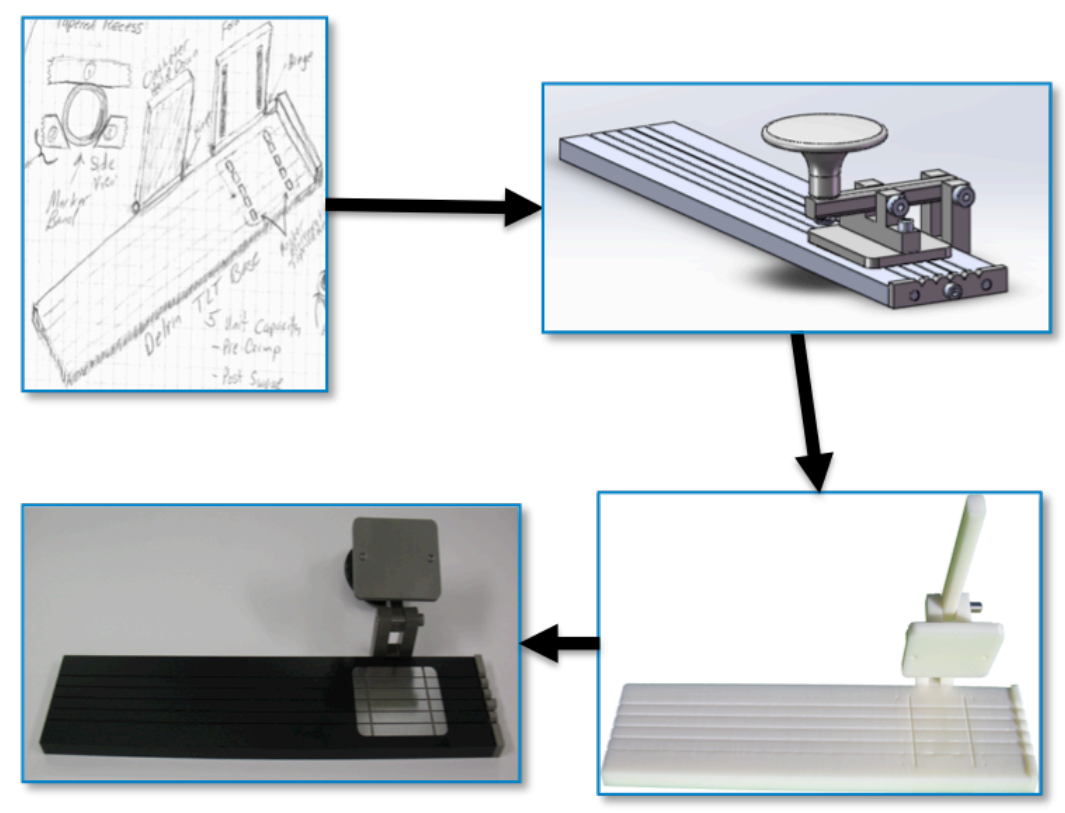

Figure 4. Verification Tool (Tool \#2)

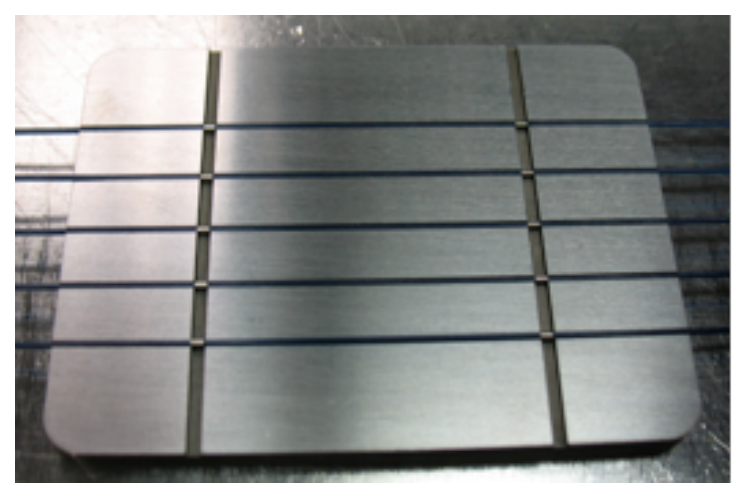

This project illustrates the benefits that corporations can enjoy by offering support for student projects. Not only did the students design and implement two related tools, which would have been sufficient to satisfy the capstone requirements, but they also successfully implemented a manufacturing test of the tools. This helped their corporate sponsor to accelerate their full-scale implementation. In addition, the students were also able to clearly demonstrate their cost-savings projections. Indeed, as this project ended, a new team within Abbott Vascular began validating these new devices for formal manufacturing. With such strong buy-in by the corporate sponsor, a challenge for the instructor was to ensure the team understood the boundary of the National University requirements and the sponsor's needs. A second challenge was to ensure that documentation was completed in a timely manner. Despite good corporate support, the students did face challenges in terms of time management, data analysis, and report writing.

\section{Instructor Sponsored Project}

The two different projects specified earlier were given to two different student cohorts, each consisting of 12 - 15 students ( 5 student teams). 


\section{Computer Chair Design}

Each team approached the project differently; however, both started with the goal of incorporating both innovation and functionality in order to ensure complete customer satisfaction. Each design incorporated the best industry practices and used accepted industry standards such as, the Business and Institutional Furniture Manufacturer's Association (BIFMA) guidelines considering anthropometric measurements of physiological human characteristics, office chair dimension criteria, general furniture design guidance, as well as ergonomic office chair constraints. Each team defined the key characteristics of an ergonomic chair by researching past chair designs and making comparative analysis of various ergonomic office chairs to meet the desired needs of the customer. They utilized modular design DFMA (design for manufacturing assembly) principles. Each team segmented the chair into four subassemblies namely base, seat, backrest, and armrests. Typically, the student teams started with napkin sketches that were created during the brainstorming phase of the design and then used SolidWorks in designing each and every part. Each team employed a novel approach in creating an office chair that can be customized to the individual user. Figure 5 provides a snapshot of an office chair design by one team. Three of the five teams completed the project within the allocated three months period. The remaining two teams had inter-personal issues, which made it difficult for them to work together and complete the project within the three months' time frame. One team took about seven months to complete and another about a year. Altogether, the project was a success as one of the teams received a provisional patent for its unique design.

Figure 5. Example of an Office Chair Designed for This Project
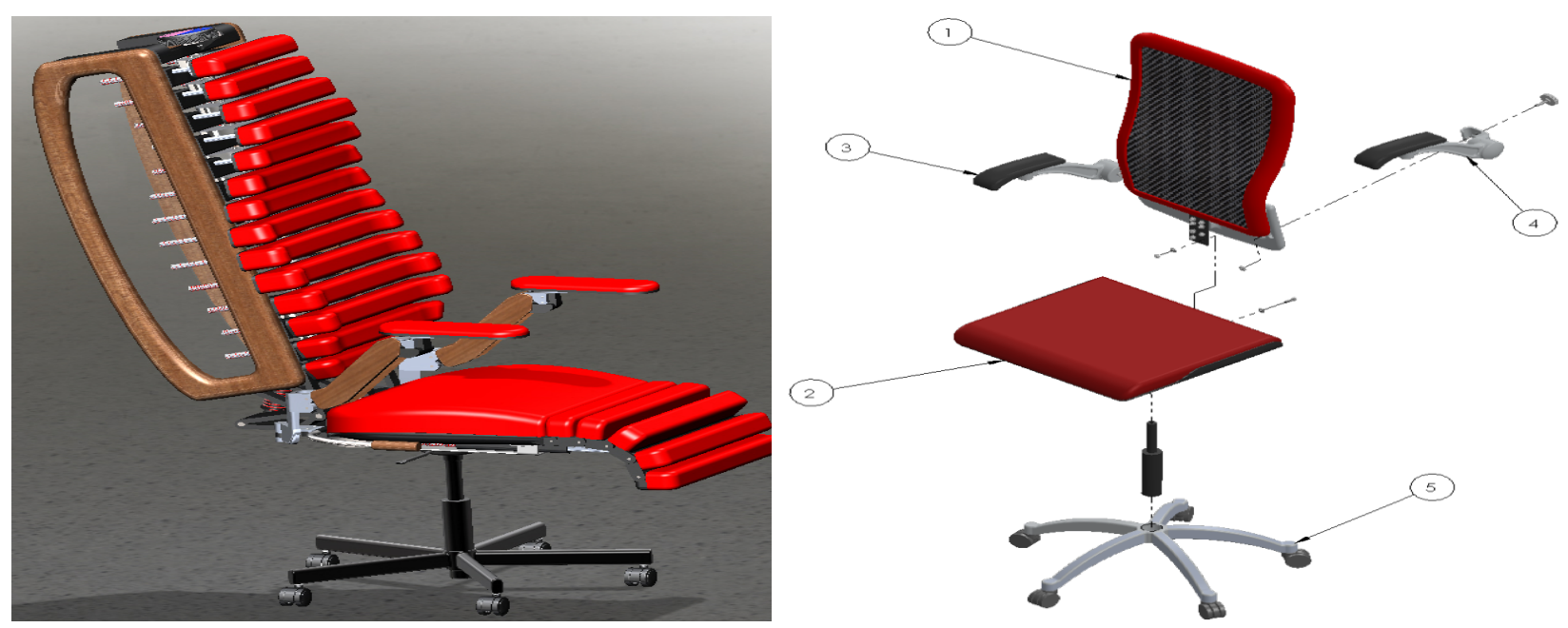

\begin{tabular}{|c|l|l|c|}
\hline Item No. & \multicolumn{1}{|c|}{ Part Number } & \multicolumn{1}{|c|}{ Description } & Qty. \\
\hline 1 & TfC000-100 & Backrest Assembly & 1 \\
\hline 2 & TFC000-400 & Seat Pan Assembly, RH & 1 \\
\hline 3 & TFC000-200 & Armrest Assembly, RH & 1 \\
\hline 4 & TFC000-300 & Armrest Assembly, LH & 1 \\
\hline 5 & TFC000-500 & Chair Base Assembly & 1 \\
\hline
\end{tabular}

\section{Motor Cycle Helmet}

Each team segmented the helmet into five parts namely, outer shell, impact absorbing liner, comfort liner, retention strap system, and face shield (visor) as illustrated in Table 2. Each team approached the project by designing and testing using SolidWorks tools. The materials were selected on the basis of strength, durability, weight, and cost. 
Table 2. Helmet Design Methodology Adopted

\begin{tabular}{|c|c|c|c|c|}
\hline Component & Functionality & $\begin{array}{l}\text { Criteria Used for } \\
\text { Selection }\end{array}$ & Material Used & Testing Methodology \\
\hline Outer Shell & $\begin{array}{l}\text { Has to have a strong and } \\
\text { rigid shell so as to limit } \\
\text { and absorb impact }\end{array}$ & $\begin{array}{l}\text { High strength, light } \\
\text { weight, excellent strength } \\
\text { to weight ratio, ease of } \\
\text { manufacturing and low } \\
\text { cost }\end{array}$ & Polycarbonate & $\begin{array}{l}\text { Penetration Test, Drop } \\
\text { Test and Impact Testing } \\
\text { using SolidWorks }\end{array}$ \\
\hline $\begin{array}{l}\text { Impact } \\
\text { Absorbing Liner }\end{array}$ & $\begin{array}{l}\text { This is the mid layer } \\
\text { between the outer shell } \\
\text { and the liner that is in } \\
\text { direct contact with the } \\
\text { head. }\end{array}$ & $\begin{array}{l}\text { Excellent energy } \\
\text { absorbing characteristics, } \\
\text { light weight, ease of } \\
\text { manufacturing and low } \\
\text { cost }\end{array}$ & $\begin{array}{l}\text { Expanded Polystyrene } \\
\text { (EPS) foam }\end{array}$ & $\begin{array}{l}\text { Material and associated } \\
\text { property analysis }\end{array}$ \\
\hline Comfort Liner & $\begin{array}{l}\text { This, being the interior } \\
\text { liner should have soft } \\
\text { padding, foam and fabric } \\
\text { lining, must provide } \\
\text { comfort, and should be } \\
\text { breathable, removable, } \\
\text { and washable. }\end{array}$ & $\begin{array}{l}\text { Comfort in the form of } \\
\text { ventilation, physical } \\
\text { comfort, helmet's snug } \\
\text { fit, and easy clean }\end{array}$ & $\begin{array}{l}\text { Ethylene Vinyl Acetate } \\
\text { (EVA) foam wrapped in } \\
\text { a microfiber polyester } \\
\text { fabric }\end{array}$ & $\begin{array}{l}\text { Material and associated } \\
\text { property analysis }\end{array}$ \\
\hline $\begin{array}{l}\text { Retention strap } \\
\text { system }\end{array}$ & $\begin{array}{l}\text { This outer most section } \\
\text { of the restraining system } \\
\text { is fundamental in } \\
\text { keeping the helmet } \\
\text { fastened to the head. }\end{array}$ & $\begin{array}{l}\text { Light weight and high } \\
\text { strength }\end{array}$ & Nylon webbing & $\begin{array}{l}\text { Retention system test } \\
\text { simulation under a } 50 \\
\text { pound load for } 30 \\
\text { seconds and while under } \\
\text { a } 250 \text { pound load for } 120 \\
\text { seconds }\end{array}$ \\
\hline $\begin{array}{l}\text { Face shield } \\
\text { (or visor): }\end{array}$ & $\begin{array}{l}\text { Generally, a clear or } \\
\text { tinted visor designed to } \\
\text { provide protection from } \\
\text { wind and debris }\end{array}$ & $\begin{array}{l}\text { High impact resistance, } \\
\text { low weight, low cost and } \\
\text { best heat resistance }\end{array}$ & Lexan polycarbonate & $\begin{array}{l}\text { Material review and } \\
\text { property analysis }\end{array}$ \\
\hline
\end{tabular}

The most distinctive feature on this design is the rotating chin/visor component and the mechanisms adopted. This design allows for the visor to be flipped up individually or spring-loaded locked. The rotating assembly swivels completely behind the helmet and locks in place similar to the way it locks while in "full-face" position. The sturdy spring-loaded mechanism allows for audible engagements/disengagements when locking and unlocking the visor/chin component. This design has been submitted for patent.

In addition, noise reduction was a primary focus of this design. Various components work together to achieve a relatively quiet helmet (in today's industry standards). Gaps and uneven surfaces cause excessive air turbulence. The visor is sealed shut using a spring-loaded mechanism along with an integrated lip on the visor. The rotating chin/visor component is locked in place by a sturdy spring-loaded lock that keeps the components from rattling and causing uneven surfaces on the front of the helmet. The foam liner is also a big player in noise reduction. The ear-cuff shape around the ears and hefty neck-roll keep gaps small and air-noise intrusion to a minimum. It also dampens the vibration noise coming from the air passing over the outside of the helmet.

Ventilation is achieved successfully with the minimal number of properly designed vents. This minimalistic approach to drilling ventilation holes on the shell, aids in conserving the integrity of the shell (important when testing for impact and penetration, and real-life crash situations). The combination of three intake vents and two exhaust vents, coupled with ribs in the interior liner and foam, successfully cool the head and exhaust warm/moist air out of the helmet. The slim device used to integrate Bluetooth capabilities cuts out unnecessary bulk both in terms of space and weight. 
Figure 6: Helmet Design Details
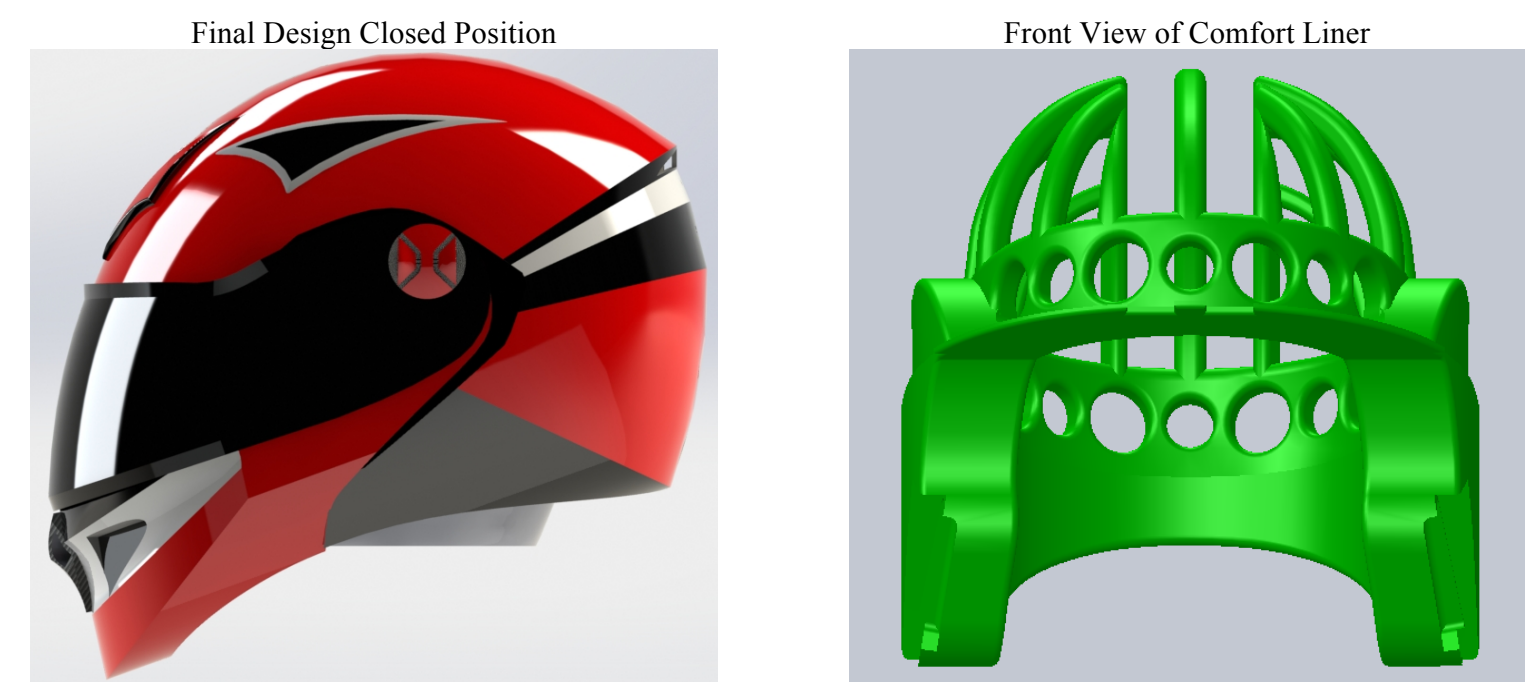

Figure 6 provides the view of final helmet design details. The capstone project teams used a rapid prototyping technique to quickly fabricate a scale model of the object using in house 3D printers (models: Cubex Trio and MakerBot Replicator $\left(5^{\text {th }}\right.$ Gen). This helped them identify the challenges they may face in manufacturing. They also integrated related course materials in the design (materials selection, strength of materials, stress analysis, optimization, cost analysis, and manufacturing strategies). However, they were unsuccessful in overcoming some of their inadequacies such as gaining greater expertise in SolidWorks simulation or improving their writing skills.

\section{CAPSTONE PROJECT EXAMINATION}

The examination for the capstone project included an oral presentation and a written document evaluation. The instructor in consultation with the program faculty appointed a committee of faculty/non-faculty members as examiners. The oral examination was used to test each student's level of knowledge and presentation skills (institutional outcome). Table 3 provides the rubric for presentation while Table 4 summarizes the rubric for the written assessment evaluation. The oral exam constituted $25 \%$, the written part $65 \%$, and participation $10 \%$ of the total score. The oral examination, typically, lasts 45 minutes; this time is further extended to accommodate questions. Copies of the capstone project are sent to the examiners for review. The students have to convince their examiners that their capstone project has made a significant contribution to knowledge. The students should also demonstrate through their project that they can successfully incorporate materials learned through the program in their product design. 
Table 3. Rubric for Capstone Project Presentation

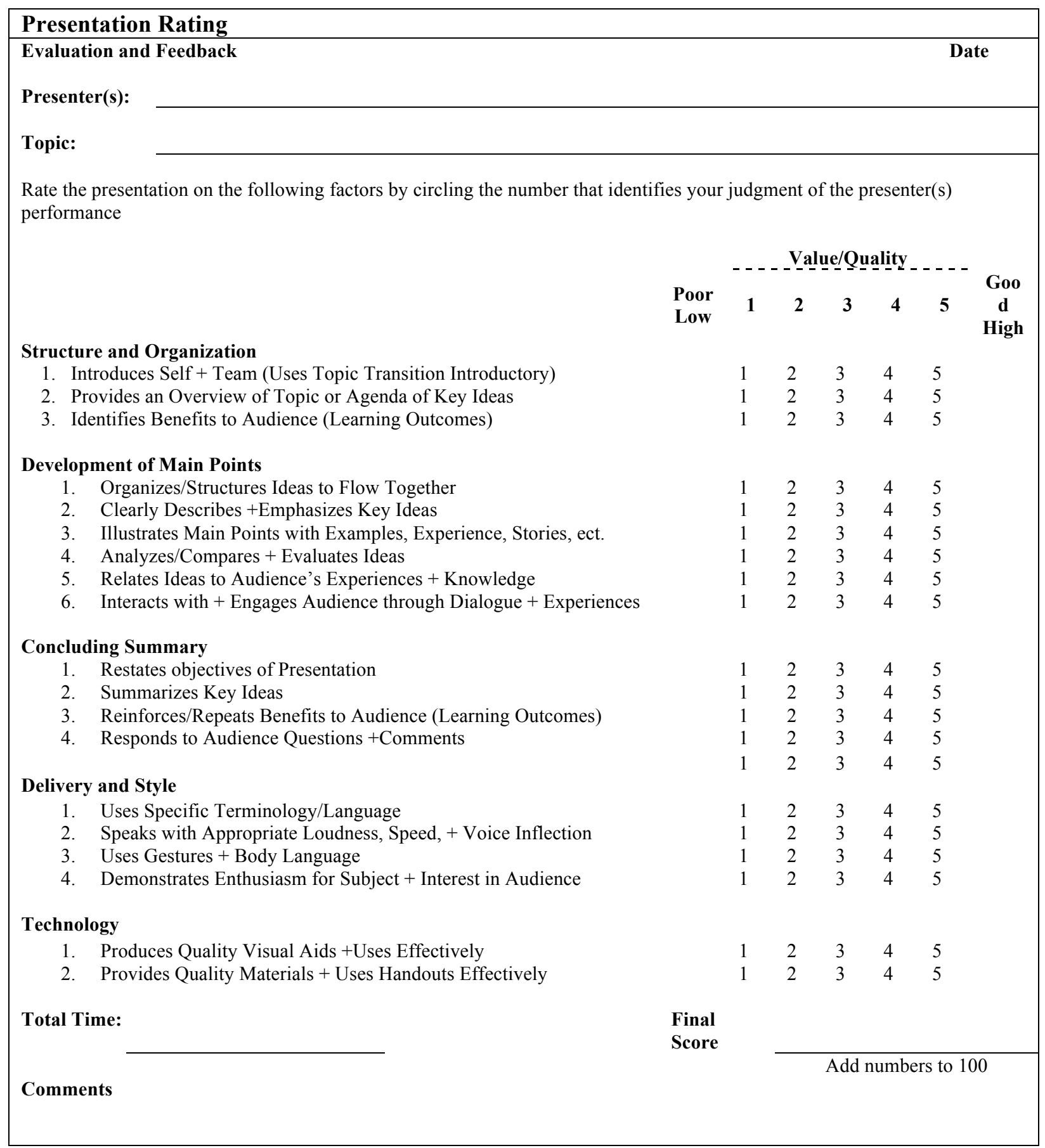


Table 4. Rubric for Written Project Evaluation

\begin{tabular}{|c|c|c|c|c|}
\hline Area & $\begin{array}{c}\text { Outstanding } \\
(9-10)\end{array}$ & $\begin{array}{c}\text { Good } \\
(7.5-9)\end{array}$ & $\begin{array}{c}\text { Fair } \\
(6-7.5)\end{array}$ & $\begin{array}{c}\text { Poor } \\
\text { (below 6) }\end{array}$ \\
\hline Facts & $\begin{array}{l}\text { Information incorporated } \\
\text { into the project } \\
\text { demonstrates considerable } \\
\text { familiarity with the } \\
\text { subject matter taught in } \\
\text { the program. }\end{array}$ & $\begin{array}{l}\text { Student could have } \\
\text { provided information } \\
\text { containing greater } \\
\text { detail and scope could } \\
\text { have been provided. }\end{array}$ & $\begin{array}{l}\text { Student had some } \\
\text { difficulty furnishing } \\
\text { sufficient evidence to } \\
\text { fully answer the } \\
\text { question. }\end{array}$ & $\begin{array}{l}\text { Student failed to } \\
\text { provide information } \\
\text { that is accurate and } \\
\text { relevant to the } \\
\text { project. }\end{array}$ \\
\hline Analysis & $\begin{array}{l}\text { Demonstrates } \\
\text { understanding of the } \\
\text { problem. Clear and } \\
\text { logical presentation of } \\
\text { facts, key concepts and } \\
\text { principles. Logically } \\
\text { sound inferences and well } \\
\text { supported conclusions. }\end{array}$ & $\begin{array}{l}\text { Demonstrates some } \\
\text { understanding of the } \\
\text { problem. Adequately } \\
\text { clear presentation of } \\
\text { facts, key concepts } \\
\text { and principles; one or } \\
\text { more erroneous } \\
\text { inference and/or } \\
\text { unsupportable } \\
\text { conclusion }\end{array}$ & $\begin{array}{l}\text { Demonstrates } \\
\text { difficulty in grasping } \\
\text { the problem. Presents } \\
\text { some of the facts, key } \\
\text { concepts and } \\
\text { principles in a mostly } \\
\text { illogical and unclear } \\
\text { fashion; makes some } \\
\text { erroneous inferences }\end{array}$ & $\begin{array}{l}\text { Demonstrates failure } \\
\text { to understand the } \\
\text { problem. Presents } \\
\text { facts, key concepts } \\
\text { and principles in an } \\
\text { unclear and illogical } \\
\text { fashion; makes } \\
\text { multiple errors in } \\
\text { reasoning. }\end{array}$ \\
\hline Synthesis & $\begin{array}{l}\text { Connects ideas and makes } \\
\text { references to other works } \\
\text { in ways that help clarify } \\
\text { how they are all } \\
\text { meaningfully connected } \\
\text { to each other. }\end{array}$ & $\begin{array}{l}\text { Brings together ideas } \\
\text { but is less effective in } \\
\text { showing the } \\
\text { connection between } \\
\text { them. Is less } \\
\text { successful in making } \\
\text { meaningful references } \\
\text { to other work }\end{array}$ & $\begin{array}{l}\text { Satisfactory factual } \\
\text { content, but is } \\
\text { presented in a } \\
\text { disjointed, fashion. } \\
\text { The report lacks } \\
\text { connection to other } \\
\text { work }\end{array}$ & $\begin{array}{l}\text { Fails to construct a } \\
\text { coherent report built } \\
\text { around an identifiable } \\
\text { organizing theme or } \\
\text { concept }\end{array}$ \\
\hline Vocabulary/Rhetoric & $\begin{array}{l}\text { Demonstrates superior } \\
\text { competence in the use of } \\
\text { subject-specific } \\
\text { terminology with } \\
\text { vocabulary in expression. }\end{array}$ & $\begin{array}{l}\text { Demonstrates } \\
\text { reasonable } \\
\text { competence in the use } \\
\text { of subject-specific } \\
\text { terminology with } \\
\text { vocabulary in } \\
\text { expression expected } \\
\text { at this grade level. }\end{array}$ & $\begin{array}{l}\text { Demonstrates less } \\
\text { than expected } \\
\text { competence in the use } \\
\text { of subject specific } \\
\text { terminology and } \\
\text { vocabulary in } \\
\text { expression at this } \\
\text { grade level }\end{array}$ & $\begin{array}{l}\text { Utilizes vocabulary } \\
\text { that is limited in } \\
\text { range }\end{array}$ \\
\hline $\begin{array}{l}\text { Mechanics and } \\
\text { Sentence Structure }\end{array}$ & $\begin{array}{l}\text { Consistently uses correct } \\
\text { grammar, syntax, } \\
\text { spelling, punctuation, and } \\
\text { capitalization. }\end{array}$ & $\begin{array}{l}\text { Has an average of } \\
\text { fewer than } 3 \text { errors } \\
\text { per page in grammar, } \\
\text { syntax, spelling, } \\
\text { punctuation, and } \\
\text { capitalization. }\end{array}$ & $\begin{array}{l}\text { Has an average of } 3 \\
\text { or } 4 \text { errors per page in } \\
\text { grammar, syntax, } \\
\text { spelling, punctuation, } \\
\text { and capitalization. }\end{array}$ & $\begin{array}{l}\text { Has an average of } \\
\text { more than } 4 \text { errors per } \\
\text { page in grammar, } \\
\text { syntax, spelling, } \\
\text { punctuation, and } \\
\text { capitalization. }\end{array}$ \\
\hline Form & $\begin{array}{l}\text { Organizes ideas into } \\
\text { coherent paragraphs with } \\
\text { smooth transitions. Good } \\
\text { overall structure. }\end{array}$ & $\begin{array}{l}\text { Organizes ideas into } \\
\text { coherent paragraphs, } \\
\text { Some awkward } \\
\text { transitions. }\end{array}$ & $\begin{array}{l}\text { A good overall } \\
\text { structure. Fails to use } \\
\text { transition words and } \\
\text { phrases to show } \\
\text { connections between } \\
\text { ideas, sentences, and } \\
\text { paragraphs }\end{array}$ & $\begin{array}{l}\text { Does not demonstrate } \\
\text { any understanding of } \\
\text { paragraph structure, } \\
\text { transitions, coherence } \\
\text { or unity. }\end{array}$ \\
\hline $\begin{array}{l}\text { Research (if } \\
\text { applicable) }\end{array}$ & $\begin{array}{l}\text { Uses a wide variety of } \\
\text { informative and relevant } \\
\text { sources, and seamlessly } \\
\text { integrates them into the } \\
\text { body of the project. }\end{array}$ & $\begin{array}{l}\text { Uses a sufficient } \\
\text { number of sources } \\
\text { and except in a one or } \\
\text { two instances, } \\
\text { effectively integrates } \\
\text { them into the body of } \\
\text { the project. }\end{array}$ & $\begin{array}{l}\text { Provides sources but } \\
\text { has difficulty } \\
\text { integrating them } \\
\text { effectively into the } \\
\text { body of the project. } \\
\text { One or more of the } \\
\text { sources is of } \\
\text { questionable } \\
\text { relevance or quality. }\end{array}$ & $\begin{array}{l}\text { Fails to provide } \\
\text { sufficient relevant } \\
\text { sources for this } \\
\text { assignment and/or } \\
\text { fails to adequately } \\
\text { incorporate outside } \\
\text { sources into the body } \\
\text { of the project. }\end{array}$ \\
\hline
\end{tabular}




\section{CONCLUSIONS AND RECOMMENDATIONS}

Based on this work, a number of conclusions including recommendations in the form of Do's and Dont's list can be drawn. Each team focused on customer requirements namely form, function, quality, sustainability, and cost. The final output included complete design, manufacturing drawings, bill of materials, cost, and manufacturing strategy. In addition, each team performed risk analysis and provided appropriate solutions to counter possible problems.

Do's and Don'ts Lists:

From this work, the following list relating to what should be or should not be done was generated.

- The students had difficulty in defining the problem initially as some could not comprehend the independent and dependent variables and defining objective function. This can be avoided by enforcing a clearly defined proposal at the beginning.

- The project selected should focus on the application of materials learned throughout the program to solve multi-faceted problems such as those they would encounter in the students' post-academic employment. The capstone projects typically are narrowly focused and hence they do not cover a wideranging subject matter. Hence the selection of the project must be given great care so that the project does not become a simple assignment.

- The projects selected must be easy to comprehend; at the same time, they should provide students with the opportunity to apply concepts from many courses and develop their critical thinking and analytical skills.

- Typically, students select their team members for capstone project. The success of a project often depends on positive team dynamics. In fact, this was found to be the most critical issue for completing the projects on time. Unfortunately, good students most often join together to form teams and this leaves the academically weak students to fend for themselves. To avoid such a situation, a skill matrix of all students has to be developed to assist students in forming teams.

- The 'front end' project plan and the 'back end' documentation and presentation are both important elements. Many team members lack good report writing skills and, as a result, they require additional help. The writing courses taken during the program are often insufficient to give students the skills they need to write a capstone project report. In addition, constant pressure has to be exercised to get the students to complete each chapter. The students must be provided with more instruction in report writing so that they develop the necessary skills and the motivation and confidence to present their project in writing.

- Since the students are apprised of all issues relevant to every phase the project, they are faced with no surprises. In addition, the students are given periodic feedback on their work. The students' enthusiasm is high due to the support provided by the project advisor, instructor, lead faculty, and sponsors. In fact, several teams have successfully completed their work as per the schedule despite undertaking very innovative designs. One of the student teams has even applied for a provisional patent for their design. This serves as an example to show that students can maximize their learning potential as long as they have a support group they can turn to at every phase of their project.

- Care must be exercised to make sure

$\circ$ the selected projects are doable within the time period

- adequate data is readily available

$\circ$ the project is in the area of manufacturing design engineering

$\circ$ the project does not depend on one student.

- The capstone process has exposed some of the deficiencies in the program including materials covered, instruction, and instructors. Based on the results obtained, it is clear that the duration of the capstone project should be extended to three courses from the current two courses.

- Integrating a project based assignment for the entire program duration would benefit the students in understanding how a final capstone project has to be done. It would also be useful to assign one specific project to an entire class so that it would be possible to compare and evaluate the solutions offered by the different teams of students. 


\section{ACKNOWLEDGEMENT}

Part of this paper was presented at the $121^{\text {st }}$ ASEE annual Conference \& Exposition in Indianapolis in 2014. The author acknowledges the work done by the students and National University for providing funds

\section{AUTHOR BIOGRAPHY}

Shekar Viswanathan has a PhD in Chemical Engineering and M.B.A. in General Management. He has 20 years of industrial experience and 19 years of teaching experience. He has successfully directed over 100 capstone projects.

\section{REFERENCES}

ABET (2016). Criteria for Accrediting Engineering Programs. Engineering Accreditation Commission, Accreditation Board for Engineering and Technology, Baltimore, MD. Worldwide web address: http://www.abet.org

Dutson, A.J., Todd, R.H., Magleby, S.P. \& Sorenson, C.D. (1997). A review of literature on teaching engineering design through project-oriented capstone courses. Journal of Engineering Education, Volume 86, Issue 1, 17-28.

Franchetti, M., Hefzy, M. S., Pourazady, M., \& Smallman, C. (2012). Framework for implementing engineering senior design capstone courses and design clinics. Journal of STEM Education: Innovations \& Research, 13(3), 30-45.

Mosher, G. A. (2015). Creating and sustaining high-quality senior capstone experiences. ATMAE Conference Proceedings: Building Bridges. 334-340, Nov 11-14, Pittsburgh, PA, USA.

Omar, M.A. (2014). Design and implementation of a capstone course to satisfy the industry needs of virtual product development and ABET engineering criteria. Education Research International.

Todd, R. H., Magleby, S.P., Sorensen, C.D., Swan, B.R. \& Anthony, D.K. (1995). A survey of capstone engineering courses in North America. Journal of Engineering Education, vol. 84, no. 2, 165-174.

Viswanathan, S. and H. Evans, (2005). Effective capstone/masters projects - Do's and don'ts. Presented at the ASEE Annual Conference, June 12-15, Portland, Oregon, USA.

Viswanathan, S. and G. Bright (2014). Effective capstone project in manufacturing design engineering program. Presented at the $121^{\text {st }}$ ASEE Annual Conference \& Exposition, June 15-18, Indianapolis, IN.

Ward, Thomas A. (2013). Common elements of capstone projects in the world's top-ranked engineering universities. European Journal of Engineering Education, 38(2), 211-218.

Zhou, Z., \& Pazos, P. (2014). Managing engineering capstone design teams: A review of critical issues and success factors. IIE Annual Conference Proceedings, 3006-3011. 


\section{NOTES}

